\title{
Reviewer Acknowledgements for Global Journal of Health Science, Vol. 13, No. 10
}

Global Journal of Health Science wishes to acknowledge the following individuals for their assistance with peer review of manuscripts for this issue. Their help and contributions in maintaining the quality of the journal are greatly appreciated.

Global Journal of Health Science is recruiting reviewers for the journal. If you are interested in becoming a reviewer, we welcome you to join us. Please contact us for the application form at: gjhs@ccsenet.org.

\section{Reviewers for Volume 13, Number 10}

Althea Jane Gamble Blakey, University of Otago, New Zealand

Ama Pokuaa Fenny, University of Ghana, Ghana

António Calha, Polytechnic Institute of Portalegre, Portugal

Farahnaz Amini, UCSI University, Malaysia

Gavric Zivana, University Banja Luka, Bosnia and Herzegovina

Jaime Hinzpeter, Clinical Hospital University of Chile, Chile

José Joaquín Mira, Universidad Miguel Hernández, Spain

Kartheek R Balapala, University Tunku Abdul Rahman, Malaysia

Loray Daws, British Columbia Masterson Institute, Canada

Pi-Ming Yeh, Missouri Western State University, United States

Piotr Raźniak, Pedagogical University, Poland

Robert Sloan, Kagoshima University Graduate School of Medical and Dental Sciences, Japan

Samir Othman, Hawler Medical University, Iraq

Soo Hoo Soon Yeng, Royal North Shore Hospital, Australia

Soontareeporn Meepring, Naresuan University, Thailand

Thanusin Saleeon, Ministry of Public Health, Thailand 